\title{
A Study on Biopolymers Synthesized from Soybean oil And Cardanol Based Dye by FTIR, DSC And TG,
}

\author{
B. Satapathy ${ }^{1}$,N.C. Pal ${ }^{*}$ \\ ${ }^{1}$ Laboraratory of Polymers and Fibers, P.G. Department of Chemistry, Ravenshaw University, \\ Cuttack, Odisha, India \\ *Department of Chemistry, Shailabala Women's College, Cuttack, Odisha, India \\ Correspondence Address :Dr. Narayan Chandra Pal, Reader in Chemistry
}

\begin{abstract}
Synthetic biopolymers has been synthesized form glycerol modified soybean oil polyurethane and cardanol based liquid amino dyes by the use of benzoyl peroxide (BPO) as initiator and ethylene glycol dimethacrylate (EGDM) as cross linker in different NCO/OH ratios with DPMDI and TDI. The polymer so produced has been characterised by different methods like FTIR, TGA, and DSC. The Synthetic Polymers so produce can be used in different industrial applications in place of petroleum based products.

Keywords: Cardanol, Soybean Oil, Polyurethane, Benzoyl Peroxide, Ethylene glycol di-methacrylate (EGDM), Diphenyl methane di-isocyanate (DPMDI), Toluene 2, 4 di-isocynate (TDI)
\end{abstract}

\section{INTRODUCTION}

The urgent need of today is to develop polymers that are bio-degradable and eco-friendly. As soybean oil is a vegetable oil abundant in supply and relatively low cost, it has become an alternative source to synthesis polyols. About $40 \%$ of standard petroleum polyols have now been replaced by soybean oil. The other compound cardanol obtained by vacuum distillation from cashew nut shell liquid ( CNSL) is also an agricultural product and an excellent monomer for synthetic polymer. IPNs from renewable resources were initiated by Sperling and Co. [1-3]. A number of articles are published [4-8] in this field with monomers derived from cardanol with other oils like castor oil, lin seed oil etc. Soybean oil is a chemical mixture of glycerides and unsaturated fatty acids. These synthetic polymer can be used in different field like adhesives binders, paints, varnishes coatings of different articles etc. due to its higher thermal stability and mechanical strength. In this paper authors have synthesised the polymer and characterised it by FTIR $[9,10]$, TGA $[12,13]$, DSC [14].

Materials:

\section{Experimental Section}

- Refined soybean oil was obtained from market.

- Cardanol was obtained from fractional distillation of CNSL liquid, a by-product of cashew Industry of South India.

- $\mathrm{NaOH}, \mathrm{MEK}, \mathrm{EGDM}, \mathrm{NaNO}_{2}, \mathrm{HCl}, \mathrm{PbO}$ etc. was obtained from M/S BDH. Ltd. (INDIA)
- TDI, DPMDI, 3-amino benzoic acid and 4-amino benzoic acid from E merk (GERMANY).

All chemicals were used as received.

\section{METHOD}

1.Spectroscopic analysis- FTIR (Fourier transform infrared): FTIR spectra of the prepared IPNs samples have been recorded on FTIR Spectrophotometer by Thermo Electric Corporation, USA, and Model: Nicolet 670 FT-IR using $\mathrm{KBr}$ pallete in the wavelength range of $500 \mathrm{~cm}^{-1}$ to $4000 \mathrm{~cm}^{-1}$.

2. Thermal Analysis (DSC and TGA): DSC and TGA of all IPNs have been performed by use of a Universal v4.5A.TA instrument (Model SDT Q 600 V20.9 Build 20) at a heating rate of $10^{\circ} \mathrm{c} /$ minute.

3. Morphology study (SEM): Morphology of samples has been studied by JOEL scanning electron microscope (SEM) Model JSM 500. For this the fractured samples have been coated with a thin layer of gold- platinum alloy by sputtering to provide conductive surface.

4. Test for biodegradability: The environmental resistance of the IPNs samples was carried out using soil burial test.

\section{Experimental :-}

i. Preparation of dye monomer: $6.85 \mathrm{~g}$ of 4 amino benzoic acid was dissolved in $13 \mathrm{~mL}$ of conc. $\mathrm{HCl}$ acid and $5 \mathrm{~mL}$ of water was added to it. The solution was cooled $0^{0}-5^{\circ} \mathrm{C}$, and then a cold solution of sodium nitrite $(4 \mathrm{~g}$ in $20 \mathrm{~mL}$ of water) was added to it slowly with stirring for 3-4 
minutes. A cold solution of cardanol $(15 \mathrm{~g}$ in $45 \mathrm{ml}$ ) of $10 \% \mathrm{NaOH}$ solution was prepared. Then cold diazonium solution was added slowly to the alkaline cardanol solution with stirring. A brilliant reddish brown coloured semi liquid dye was formed. The dye was separated by a separating funnel. The same procedure is repeated for 3-amino benzoic acid.

ii. Preparation of Mixed Ester Polyol (MEP) from Soybean Oil (SO): Refined soybean oil $(350 \mathrm{~mL})$ was heated at $250^{\circ} \mathrm{C}$ in an inert Nitrogen atmosphere taken in three naked flask fitted with a thermometer reflux condensers and a stirrer. At this temperature litherage $(0.168 \mathrm{~g})$ and glycol $(80 \mathrm{~mL})$ were added to the reaction mixture with constant stirring. The temperature was maintained at $250^{\circ} \mathrm{C}$ until one volume of reaction mixture gave a clear solution in same volume methanol. At this stage the contents were cooled to obtain MEP.

iii. Synthesis of Polyurethane (PU): 1 mole of MEP was added to 1.6 mole of TDI to maintain $\mathrm{NCO} / \mathrm{OH}$ ratio at 1.6 . The reaction was carried out at $45^{\circ} \mathrm{C}$ with continuous stirring for one hour until a viscous pale yellow colour $\mathrm{PU}$ is separated out. The same process was repeated with different $\mathrm{NCO} / \mathrm{OH}$ ratio $(1.2,1.6$, and 2.0$)$ and with other di-isocyanate DPMDI PUs was produced.

iv. Synthesis of IPNs: The mixture of PU and diazotised cardanol (with different PU/monomer ratio i.e., $(25: 75,35: 65,50: 50)$ and solvent (MEK) were taken in small beaker. Then $5 \mathrm{~mL}$ of $10 \%$ EGDM along with 20mg of Benzoyl peroxide (BPO) were added to each mixture. The total mixture was stirred for 15 minutes with magnetic stirrer in cold to obtain a homogenous solution. Then the temperature was raised to $75^{\circ} \mathrm{C}$ and stirred until a thick solution was formed. Then the viscous mass was poured into a petridish in hot condition and kept in an oven at $75^{\circ} \mathrm{C}$ for 24 hour.

The thin film thus obtained was cooled and removed from the petridish with a sharp blade and sent for characterisation to the Central Instrumentation Facility Pondicherry University, Puducherry, pin-605014.

Soybean oil (SO): Triglyceride of linolenic acid (7$10 \%)$, linoleic acid (51\%) and oleic acid (23\%)

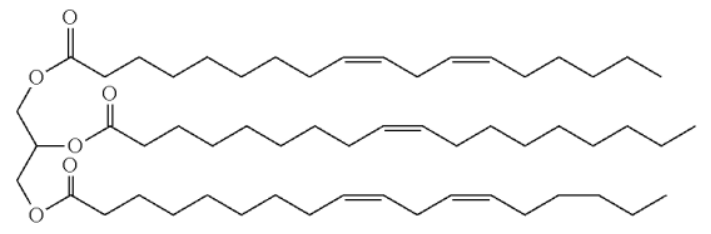

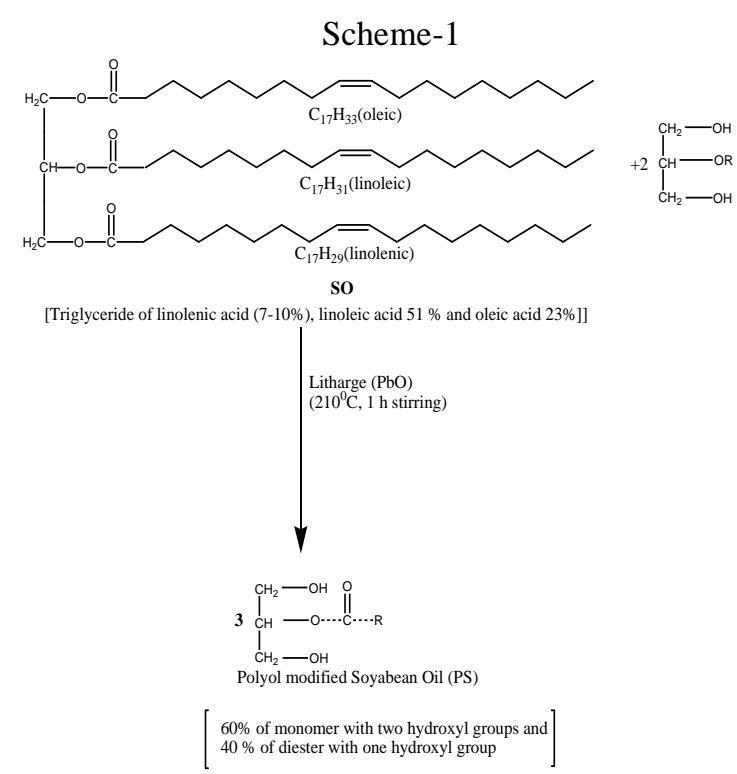

Synthesis of Polyol modified Soybean Oil (PS)

Scheme -2

(i)
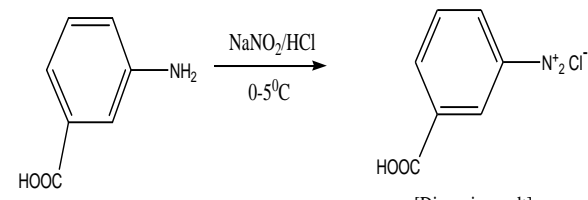

3-amino benzoic acid

[Diazonium salt]

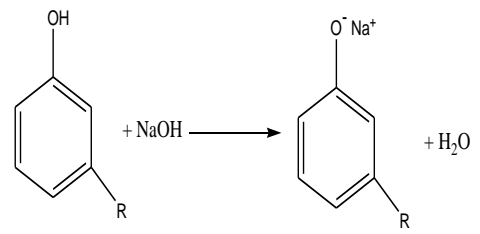

(iii)
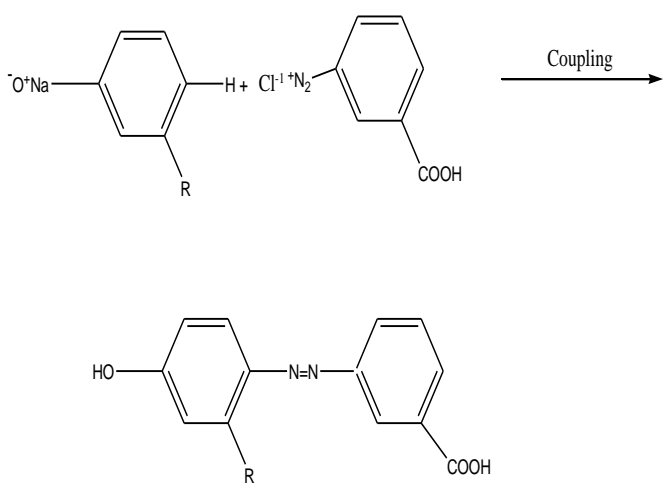

Cardanol based Dye (CD) with 3-aminobenzoic acid 
Scheme - 2a

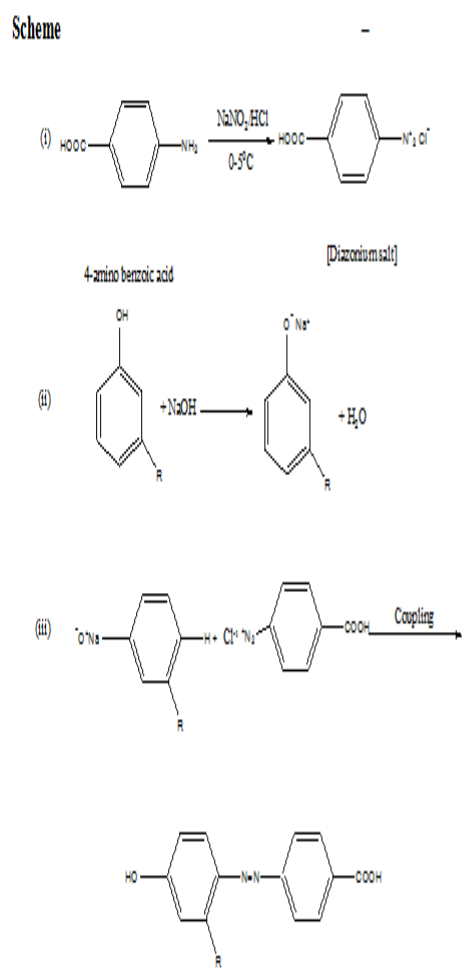

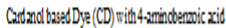

Scheme -3

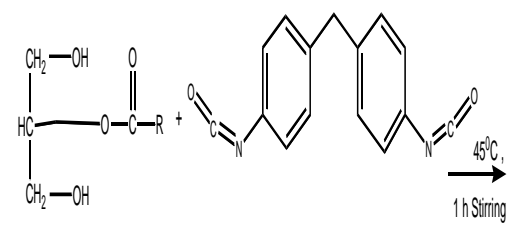

Polyol Modified Soyabean dipheny methane-4,4. disisocyanatie OIIIPS)

(DPMDI)

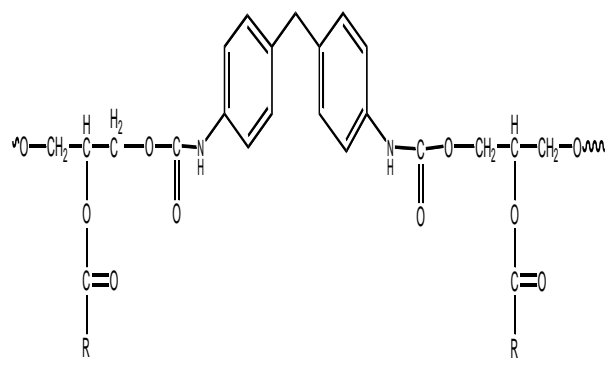

(POLYURATHANE (PU) FROM DPMDI)
Scheme $-3 a$
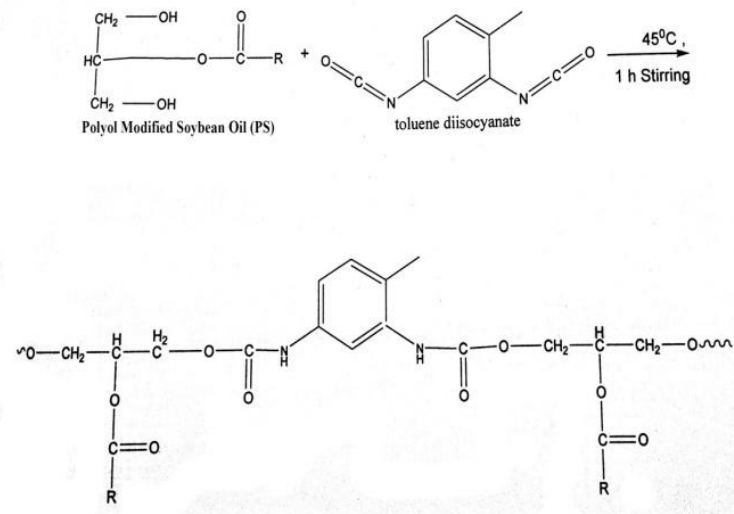

[POLYURATHANE (PU) from TDI]

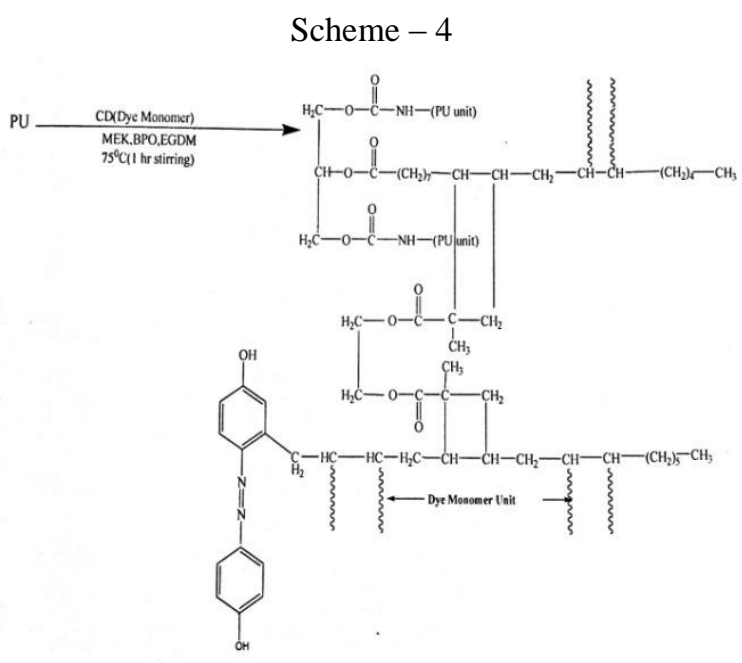

Syethesis of IPNs

[Structure of IPN synthesized from Cardonal

based dye with 4-aminobenzoic acid and

Polyurethane of glycerol modified Soybean Oil

with DPMDI]

Same procedure was followed for Polyurathane of Toluene-2,4-diisocyanate with Soybean oil and dye with 4-aminobenzoicacid and Cardanol.

\section{Analysis of the Sample:}

1. Ftir - The FTIR spectra of the IPNs 6, 10, 12, 14 and 24 are presented in figs 1 -a to 1 -e

The presence of component materials in the macromolecules was confirmed by the study of FT-IR spectra if the prepared samples.

\section{Ftir Of Ipn-6}

The characteristic absorption of IPN-6 corresponding to IPN-6 to O-H stretching of $>\mathrm{OH}$ groups shifted to lower value by hydrogen bonding at 
$3677.1 \mathrm{~cm}^{-1}$ and $3607.6 \mathrm{~cm}^{-1}$. N-H stretching of $>\mathrm{NH}$ group at $3333.5 \mathrm{~cm}^{-1}, \mathrm{C}-\mathrm{H}$ stretching (ss/as) of $>\mathrm{CH}_{2}$ and $>\mathrm{CH}_{3}$ groups at $2857.7 \mathrm{~cm}^{-1}$ and 2926.4 $\mathrm{cm}^{-1}, \mathrm{~N} \equiv \mathrm{C}$ stretching of $-\mathrm{N}=\mathrm{C}=\mathrm{O}$ group for the isocyanate terminating $\mathrm{PU}$ unit at $2341.8 \mathrm{~cm}^{-1}, \mathrm{C}=\mathrm{O}$ stretching of urethane linkage at $1662.8 \mathrm{~cm}^{-1}, \mathrm{~N}=\mathrm{N}$ stretching of azo group at $1605.7 \mathrm{~cm}^{-1}, \mathrm{C}-\mathrm{O}$ bending at $1164.2 \mathrm{~cm}^{-1}, \mathrm{C}=\mathrm{C}$ stretching at $1531.2 \mathrm{~cm}^{-1}, \mathrm{C}-\mathrm{C}$ stretching at $1453.1 \mathrm{~cm}^{-1}$, out of plane $\mathrm{C}-\mathrm{H}$ bending at $708.6 \mathrm{~cm}^{-1}$ and out of plane C-C bending at $506.3 \mathrm{~cm}$ ${ }^{1}$.were observed.

\section{Ftir Of Ipn-10}

The characteristic absorption of IPN-10 corresponding $-\mathrm{OH}$ stretching of $>\mathrm{OH}$ groups shifted to lower value by hydrogen bonding at $3837.7 \mathrm{~cm}^{-1}$. $\mathrm{N}-\mathrm{H}$ stretching of $>\mathrm{NH}$ group at $3441.2 \mathrm{~cm}^{-1}, \mathrm{C}-\mathrm{H}$ stretching (ss/as) of $>\mathrm{CH}_{2}$ and $>\mathrm{CH}_{3}$ groups at $2855.4 \mathrm{~cm}^{-1}$ and $2924.7 \mathrm{~cm}^{-1}, \mathrm{~N} \equiv \mathrm{C}$ stretching of $\mathrm{N}=\mathrm{C}=\mathrm{O}$ group for the isocyanate terminating $\mathrm{PU}$ unit at $2334.8 \mathrm{~cm}^{-1}, \mathrm{C}=\mathrm{O}$ stretching of urethane linkage at $1665.0 \mathrm{~cm}^{-1}, \mathrm{~N}=\mathrm{N}$ stretching of azo groupat 1589.8 $\mathrm{cm}^{-1}, \mathrm{C}-\mathrm{O}$ bending at $1055.2 \mathrm{~cm}^{-1}, \mathrm{C}=\mathrm{C}$ stretching at $1390.3 \mathrm{~cm}^{-1}$, C-C stretching at $1342.8 \mathrm{~cm}^{-1}$, out of plane $\mathrm{C}-\mathrm{H}$ bending at $723.3 \mathrm{~cm}^{-1}$ and out of plane C$\mathrm{C}$ bending at $450.5 \mathrm{~cm}^{-1}$ were observed.

\section{FTIR OF IPN-12}

The characteristic absorption of IPN-12 corresponding $-\mathrm{OH}$ stretching of $>\mathrm{OH}$ groups shifted to lower value by hydrogen bonding at $3834.8 \mathrm{~cm}^{-1}$. $\mathrm{N}-\mathrm{H}$ stretching of $>\mathrm{NH}$ group at $3402.4 \mathrm{~cm}^{-1}, \mathrm{C}-\mathrm{H}$ stretching (ss/as) of $>\mathrm{CH}_{2}$ and $>\mathrm{CH}_{3}$ groups at $2926.5 \mathrm{~cm}^{-1}$ and $2857.2 \mathrm{~cm}^{-1},-\mathrm{N} \equiv \mathrm{C}$ stretching of $\mathrm{N}=\mathrm{C}=\mathrm{O}$ group for the isocyanate terminating $\mathrm{PU}$ unit at $2374.3 \mathrm{~cm}^{-1}, \mathrm{C}=\mathrm{O}$ stretching of urethane linkage at $1727.6 \mathrm{~cm}^{-1},-\mathrm{N}=\mathrm{N}$ stretching of azo groupat 1604.0 $\mathrm{cm}^{-1},-\mathrm{N}=\mathrm{N}$ stretching of aromatic rings at $1542.4 \mathrm{~cm}$ ${ }^{1}$, C-O bending at $1164.2 \mathrm{~cm}^{-1}, \mathrm{C}=\mathrm{C}$ stretching at $1531.2 \mathrm{~cm}^{-1}, \mathrm{C}=\mathrm{C}$ stretching of aromatic rings at $1232.2 \mathrm{~cm}^{-1}$, C-O stretching of ester at $1160.7 \mathrm{~cm}^{-1}$, out of plane $\mathrm{C}-\mathrm{H}$ bending at $869.6 \mathrm{~cm}^{-1}$ and out of plane $\mathrm{C}-\mathrm{C}$ bending at $713.8 \mathrm{~cm}^{-1}$ were observed.

\section{FTIR OF IPN-14}

The characteristic absorption of IPN-14 corresponding to $\mathrm{N}-\mathrm{H}$ stretching of $>\mathrm{NH}$ group at $3456.9 \mathrm{~cm}^{-1}$, C-H stretching (ss/as) of $>\mathrm{CH}_{2}$ and > $\mathrm{CH}_{3}$ groups at $2925.4 \mathrm{~cm}^{-1}$ and $2856.5 \mathrm{~cm}^{-1},-\mathrm{N} \equiv \mathrm{C}$ stretching of $-\mathrm{N}=\mathrm{C}=\mathrm{O}$ group for the isocyanates at $2354.0 \mathrm{~cm}^{-1}$ and $2546.0 \mathrm{~cm}^{-1}, \mathrm{C}=\mathrm{O}$ stretching of urethane linkage at $1691.5 \mathrm{~cm}^{-1},-\mathrm{N}=\mathrm{N}$ stretching of azo groupat $1596.3 \mathrm{~cm}^{-1},-\mathrm{N}=\mathrm{N}$ stretching of aromatic rings at $1542.4 \mathrm{~cm}^{-1}, \mathrm{C}=\mathrm{C}$ stretching at $1393.2 \mathrm{~cm}^{-1}$, $\mathrm{C}=\mathrm{C}$ stretching of aromatic rings at $1244.8 \mathrm{~cm}^{-1}, \mathrm{C}-\mathrm{O}$ stretching of ester at $1166.6 \mathrm{~cm}^{-1}$, out of plane $\mathrm{C}-\mathrm{H}$ bending at $784.4 \mathrm{~cm}^{-1}$ and out of plane $\mathrm{C}-\mathrm{C}$ bending of p-substituted benzene ring at $695.2 \mathrm{~cm}^{-1}$ and 543.1 $\mathrm{cm}^{-1}$ were observed.

\section{FTIR OF IPN-24}

The characteristic absorption of IPN-24 corresponding to $-\mathrm{OH}$ stretching of $>\mathrm{OH}$ groups shifted to lower value by hydrogen bonding at 3590.8 and $3452.4 \mathrm{~cm}^{-1}$. N-H stretching of $>\mathrm{NH}$ group at $3349.2 \mathrm{~cm}^{-1}$, C-H stretching (ss/as) of $>\mathrm{CH}_{2}$ and > $\mathrm{CH}_{3}$ groups at $2921.1 \mathrm{~cm}^{-1}$ and $2861.8 \mathrm{~cm}^{-1},-\mathrm{N} \equiv \mathrm{C}$ stretching of $-\mathrm{N}=\mathrm{C}=\mathrm{O}$ group for the isocyanides at $2771.5 \mathrm{~cm}^{-1}, \quad 2619.9 \mathrm{~cm}^{-1}, 2365.4 \mathrm{~cm}^{-1}, \quad \mathrm{C}=\mathrm{O}$ stretching of urethane linkage at $1984.0 \mathrm{~cm}^{-1},-\mathrm{OH}$ bending due to $-\mathrm{COOH}$ group at $1306.7 \mathrm{~cm}^{-1},-\mathrm{N}=\mathrm{N}$ stretching of azo group at $1605.5 \mathrm{~cm}^{-1}, \mathrm{C}-\mathrm{O}$ bending at $1154.8 \mathrm{~cm}^{-1}$, C-C stretching of aromatic rings at $1399.7 \mathrm{~cm}^{-1}, \mathrm{C}=\mathrm{C}$ stretching of aromatic rings at $1518.6 \mathrm{~cm}^{-1}$, C-O stretching of ester at $1160.7 \mathrm{~cm}^{-1}$, out of plane $\mathrm{C}-\mathrm{H}$ bending at $811 \mathrm{~cm}^{-1}$ and out of plane $\mathrm{C}-\mathrm{C}$ bending of p-substituted benzene ring at $634 \mathrm{~cm}^{-}$ ${ }^{1}$ and $481 \mathrm{~cm}^{-1}$ were observed.

\section{Findings}

From the fig.1a to 1e correlation with the peak of the authentic compound helps to identify the structure of the polymer sample. Thus it is concluded that the polymer sample contains azo based compound which contain - $\mathrm{COOH},-\mathrm{OH},-\mathrm{CH}_{2},-\mathrm{CH}_{3},-\mathrm{C}-\mathrm{O}-\mathrm{C}$ stretching of $-\mathrm{OCH}_{3}$, azo groups, urethane linkage and benzene rings.

The probable structure of IPN is as in Scheme 4.

\section{Thermogravimetric Analysis}

Thermal stability of IPNs was determined by the use of Universal $\mathrm{V}_{4}$ 5ATA instrument at a rate of $10^{\circ} \mathrm{C} / \mathrm{min}$ from room temperature to $700^{\circ} \mathrm{C}$, again it is cooled from $700^{\circ} \mathrm{C}$ to room temperature. The percentage of mass left with temperature was recorded as shown in figure $2 \mathrm{a}$ to $2 \mathrm{e}$.

In this paper we have compared the thermal stability of different IPNs with varied $\mathrm{NCO} / \mathrm{OH}$ ratio and different amino acid compounds.

\section{Findings}

IPN $_{12}$ is less stable than IPN 6, IPN 10, IPN 14, IPN 24 having $0.50 / 0.50 \mathrm{PU} / \mathrm{CD}$ ratio. IPN 14 is the most stable of the five IPNs. IPNs are stable upto $180^{\circ} \mathrm{C}$ after which they decompose. In general it is observed that IPNs undergo degradation in three steps. In the first step, there is an initial weight loss which is attributed to the loss of moisture retained in the samples and elimination of smaller groups. In the second step, there is a gradual weight loss which is due to the decomposition of the urethane linkage and volatilization of low molecular weight products. In this step, the unreacted unsaturated parts (=bonds) get activated due to the presence of excess benzoyl peroxide in the macromolecules. So, in the IPN cross linking, which makes the system more rigid, occurs 
and the new cross links formed inside the macromolecules develop a strain in the macromolecular chain resulting the release of small groups outside the macromolecular structure. In the third step, it is seen that the major portion of the samples decompose because of the random scission of the cardanol backbone. In this step, the strained macromolecules suffer depolymerisation (unzipping) leading to segmental release of larger groups and leaving a charred residue as shown in Table $1 \& 2$.

Kinetics of IPNs is determined by Freeman Anderson method as per the following equation

$\Delta \log \left(-\frac{\mathrm{dw}}{\mathrm{dt}}\right)=\mathrm{n} \Delta \log \mathrm{w}-\frac{\mathrm{Ea}}{2.303 \mathrm{R}} \Delta\left(\frac{1}{\mathrm{~T}}\right)$

Where $\mathrm{n}=$ order of reaction

$\mathrm{E}_{\mathrm{a}}=$ Activation Energy

These values are determined from the plot of $\Delta \log \left(-\frac{\mathrm{dw}}{\mathrm{dt}}\right) \mathrm{vs} \Delta \log \overline{\mathrm{w}}$. The slope gives us order of reaction $\mathrm{n}$ and intercept is related to activation energy (Ea) which is given by Ea $=\frac{\text {-Intercept } \times 2.303 \mathrm{R}}{\Delta\left(\frac{1}{\mathrm{~T}}\right)}$

(As shown in fig. 3a(i) to Fig 3e (ii) and table 5.

VII. D.S.C. (Differential scanning calorimetric analysis)

In this instrument heat capacity of a sample is measured as the function of differential heat flow rate between the sample and reference material.

The instrument directly gives a recording of heat flow rate against temperature. Heat flow rate undergoes a change during transition. $\mathrm{T}_{\mathrm{g}}, \mathrm{T}_{\mathrm{c}}$ and $\mathrm{Tm}$ values can be computed from the table- 3 .

$\mathrm{T}_{\mathrm{g}}$ : Glass transition temperature

$\mathrm{T}_{\mathrm{c}}$ : Curie temperature or crystallization temperature

$\mathrm{T}_{\mathrm{m}}$ The temperature at which change of state occurs

$\mathrm{T}_{\mathrm{f}}$ : The flow point

$\mathrm{T}_{\mathrm{g}}=$ (Pre transition temperature + Post transition temperature) $/ 2$

\section{Findings}

IPN 24 has more Tg, Tc and Tm value than IPN 14 because it contains more amount of $\mathrm{PU}$ and more crystalline.

\section{Biodegradability:}

The IPN samples synthesized were tested for environmental resistance by use of soil burial test. The samples were buried in soil for sixty days. The samples were removed from the soil once in fifteen days to access the changes in their weight loss, mechanical strength and surface damage if any as shown in Table 4

\section{Findings}

From this observation (table-4) it is seen that these samples are not biodegradable, only a small amount of it decomposes with the bacteria and virus present in the soil which is very negligible but can be recycled.

\section{Conclusion}

These synthetic biopolymers highly cross linked and thermally stable, hence can be used in place of petroleum based polymers and exhibit excellent performance in various applications than the copolymers derived from simple cardanol.

\section{ACKNOWLEDGEMENT}

The authors are thankful to the Registrar,Ravenshaw University, Odisha for his kind permission to provide the laboratory facility and help to publish this paper. The authors are thankful to the Registrar, Utkal University, Bhubaneswar to publish the paper. The authors are also thankful to the Dean, Pondicherry University, Puducherry for characterisation of the samples.

Figure 1a: FTIR of IPN 6

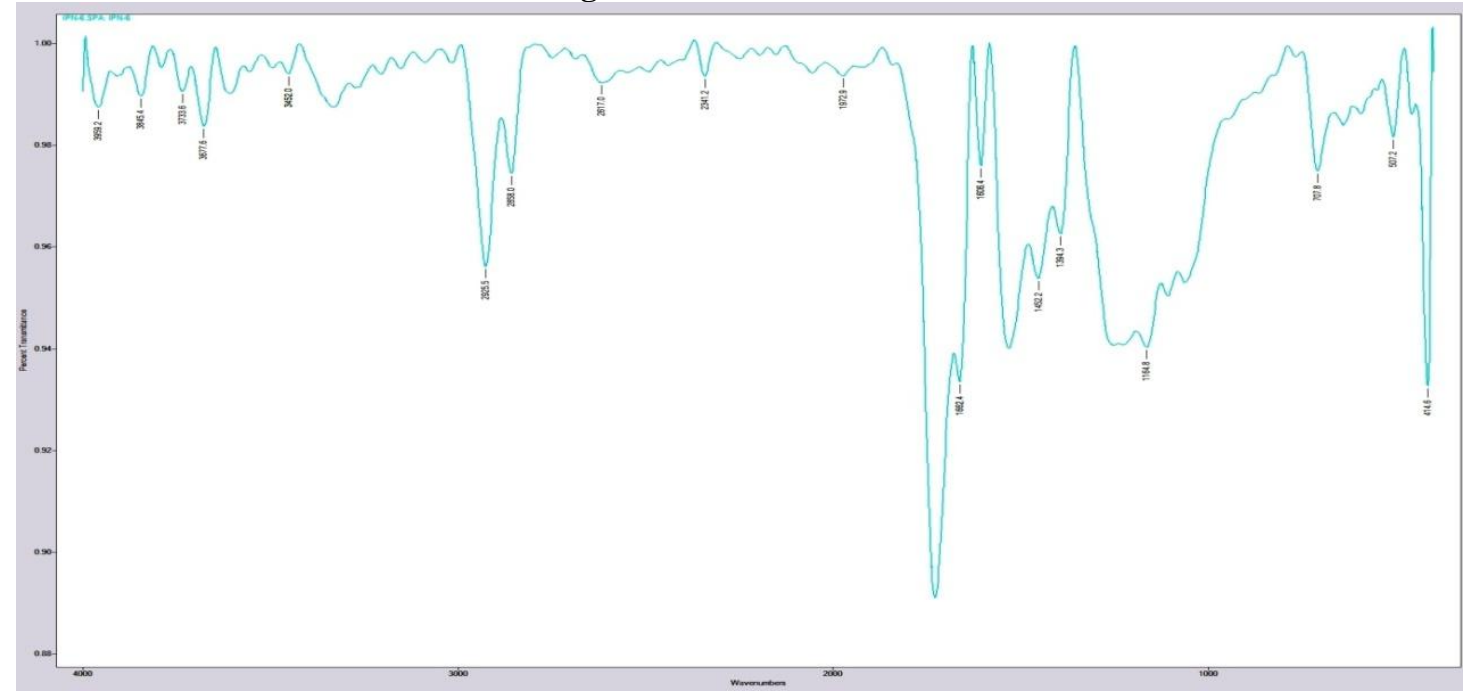


Figure 1b: FTIR of IPN 10

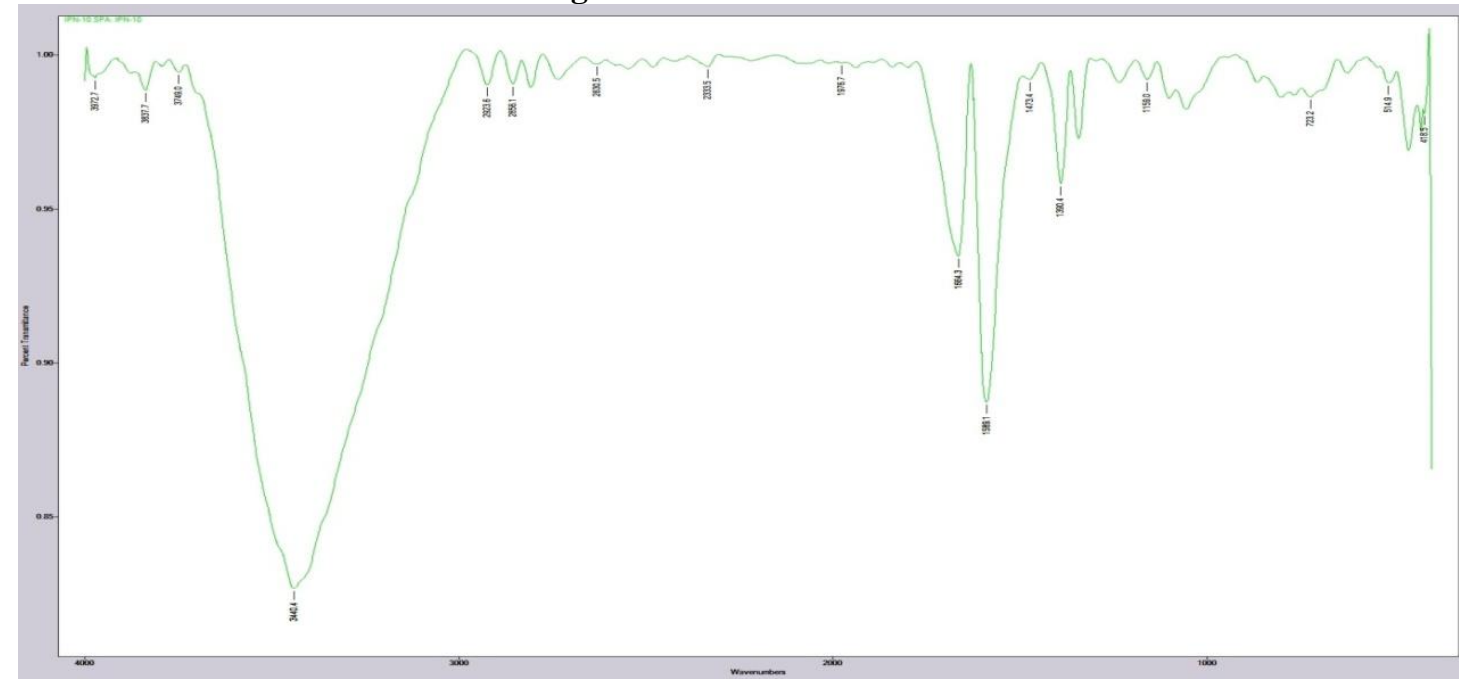

Figure 1c: FTIR of IPN 12

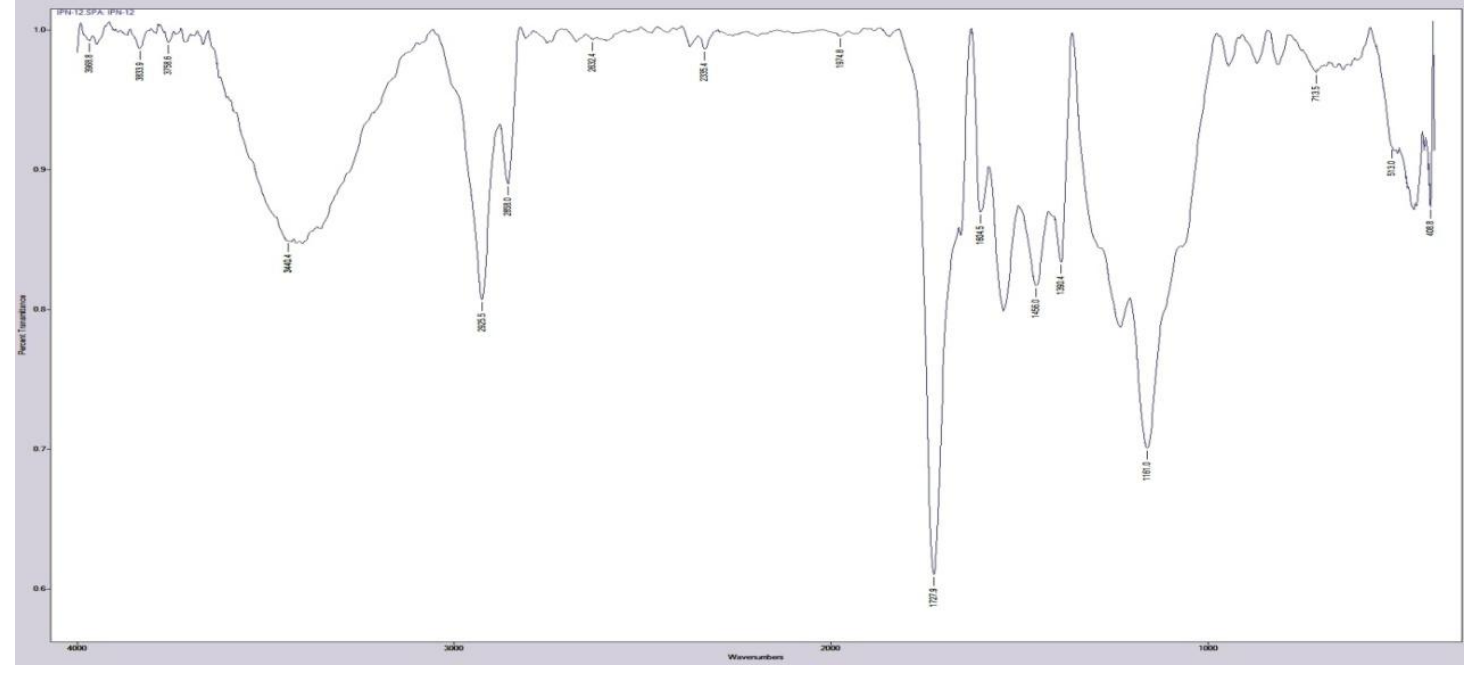

Figure 1d: FTIR of IPN 14

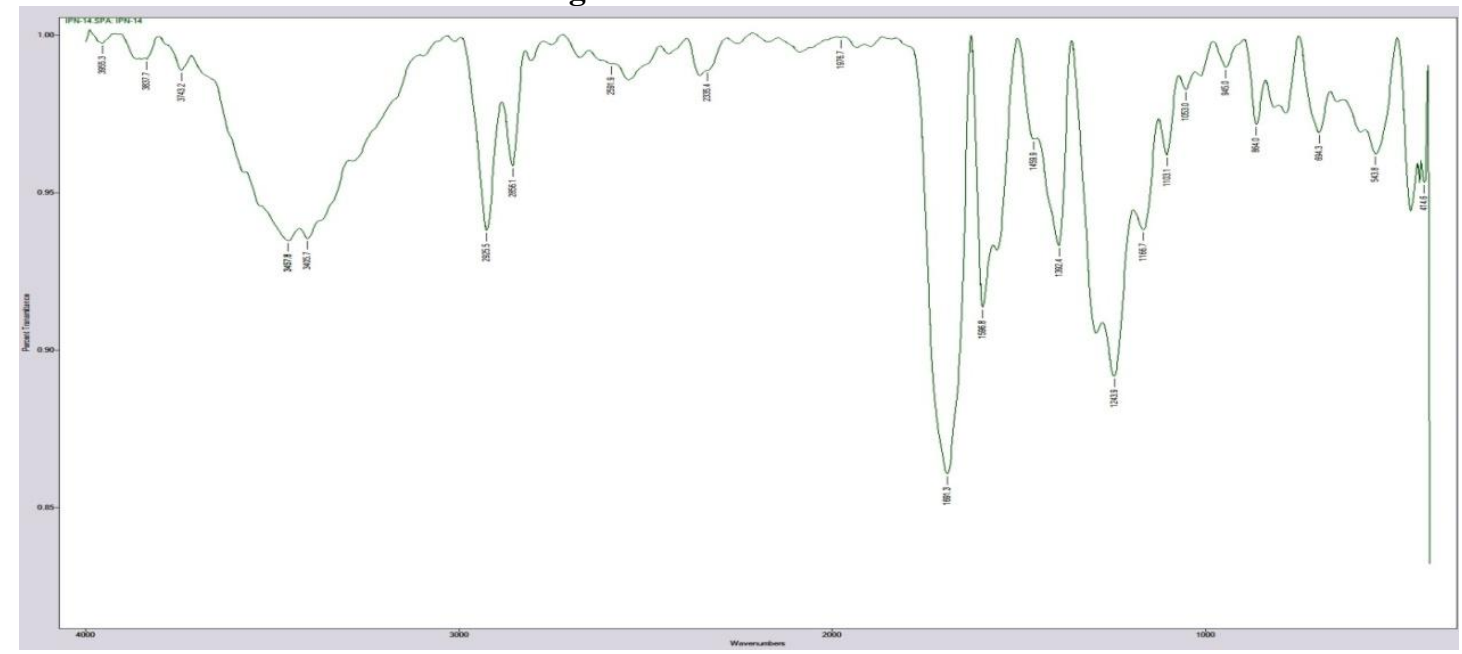


Figure 1e: FTIR of IPN 24

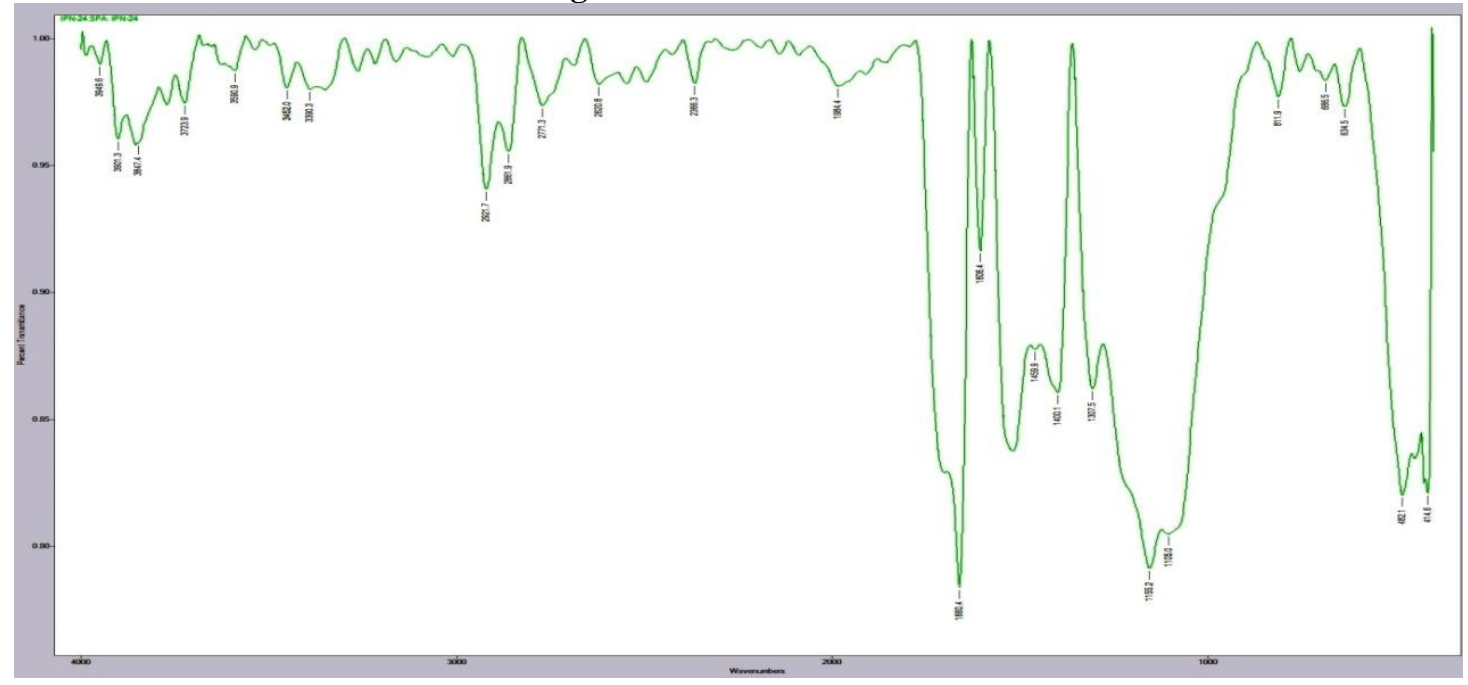

Fig2a: DSC-TGA OF IPN-6

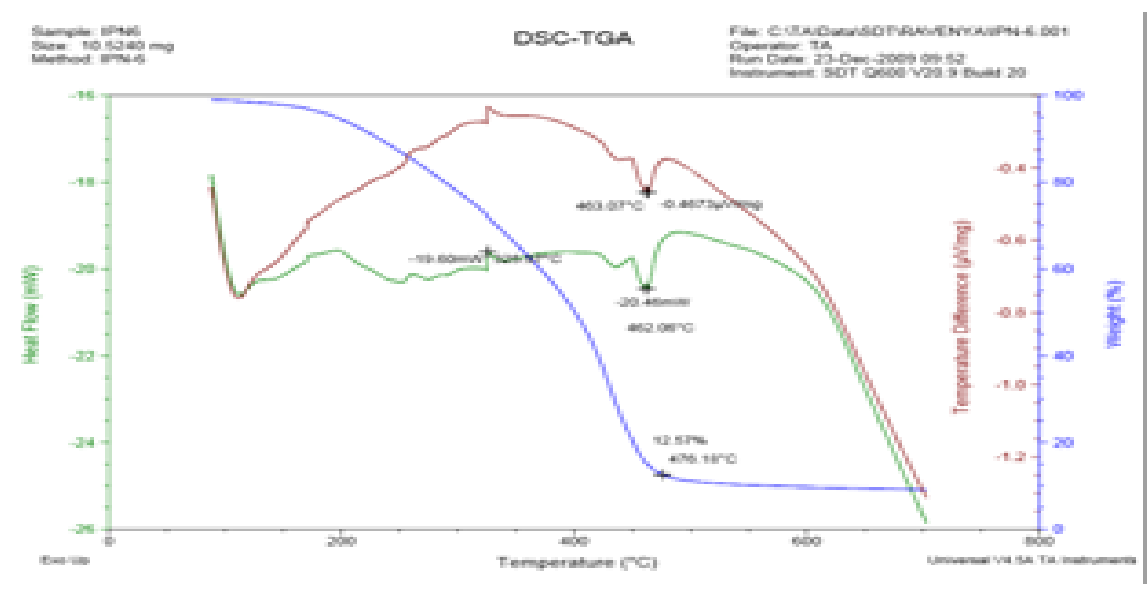

Fig 2b:DSC-TGA OF IPN-10

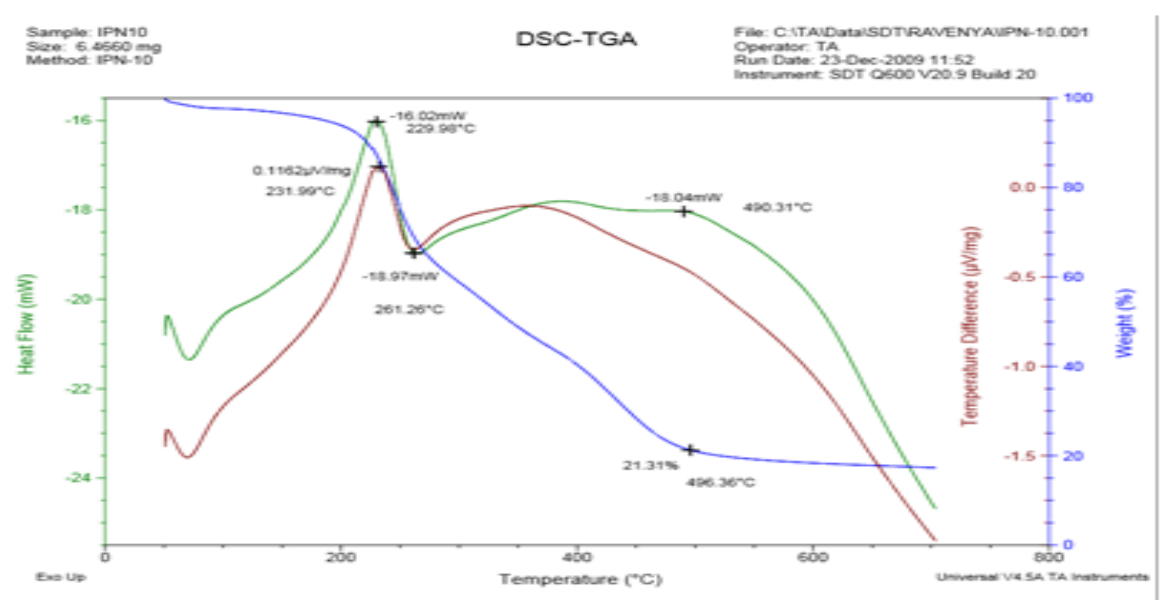




\section{Fig2c: DSC-TGA OF IPN-12}

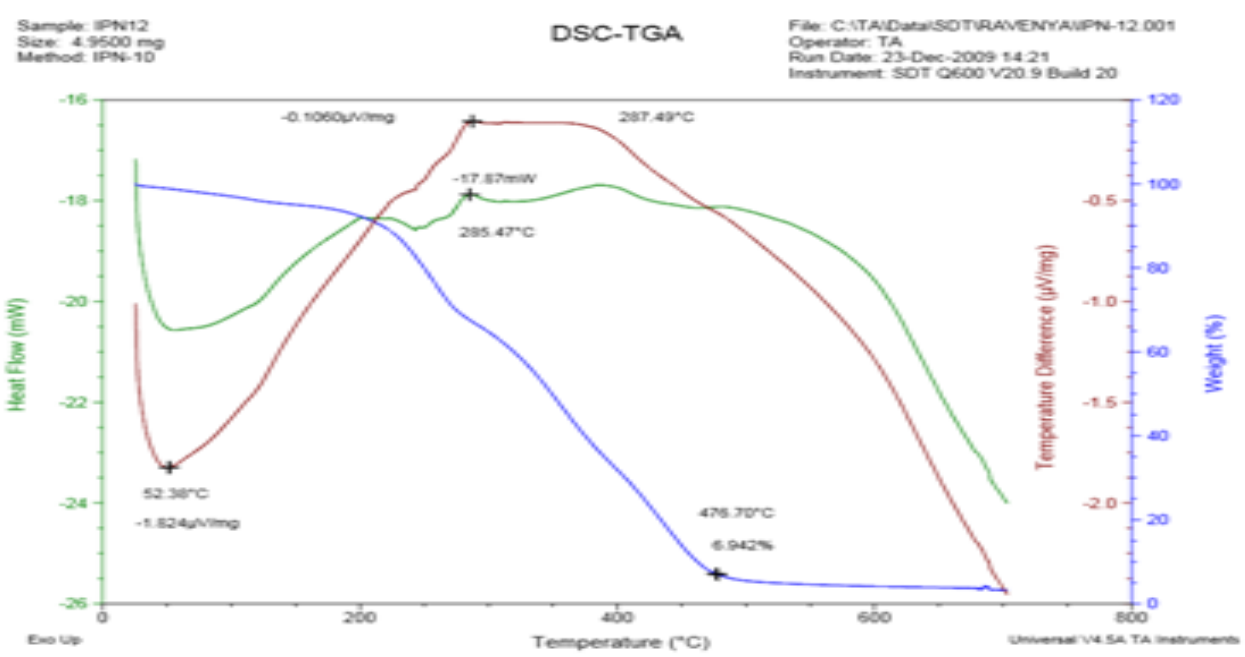

Fig2d: DSC-TGA OF IPN-14

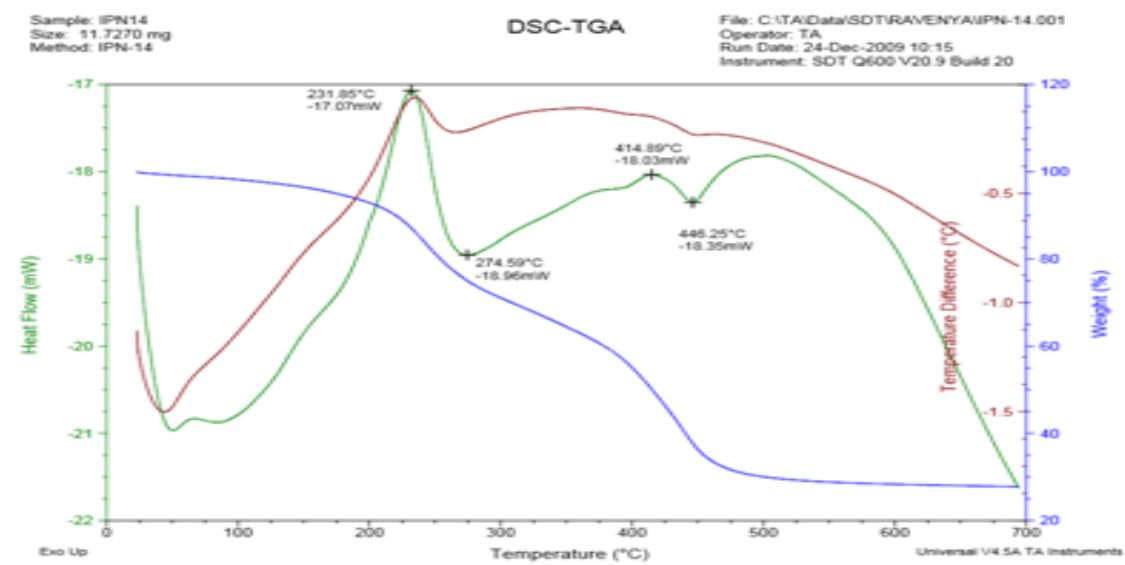

Fig2e: DSC-TGA OF IPN-24

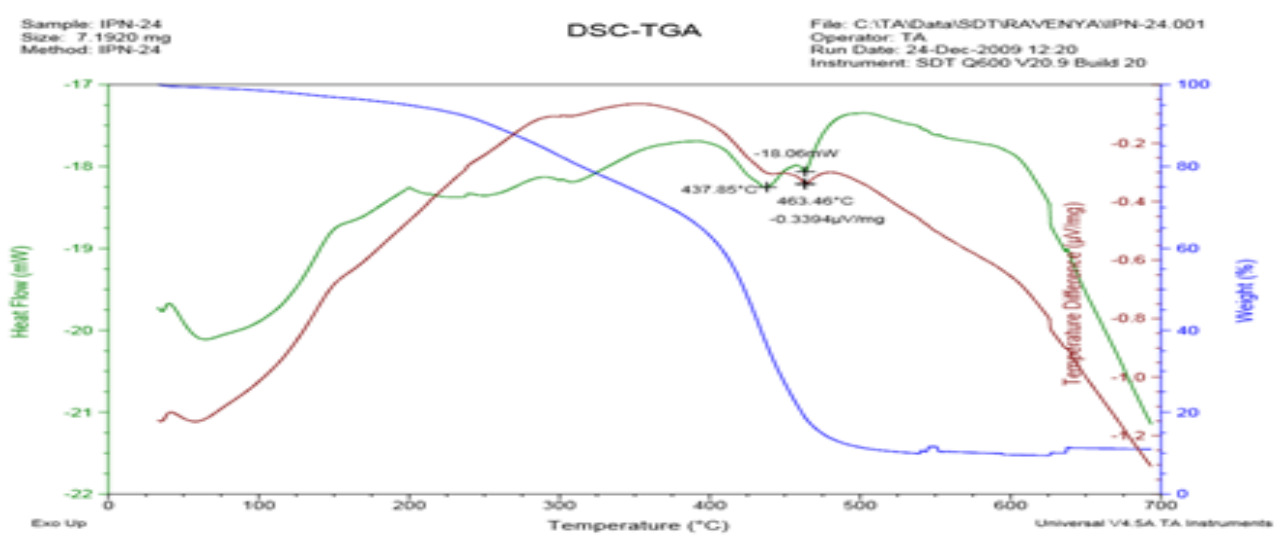


Fig 3a(i) showing kinetics of IPN-6

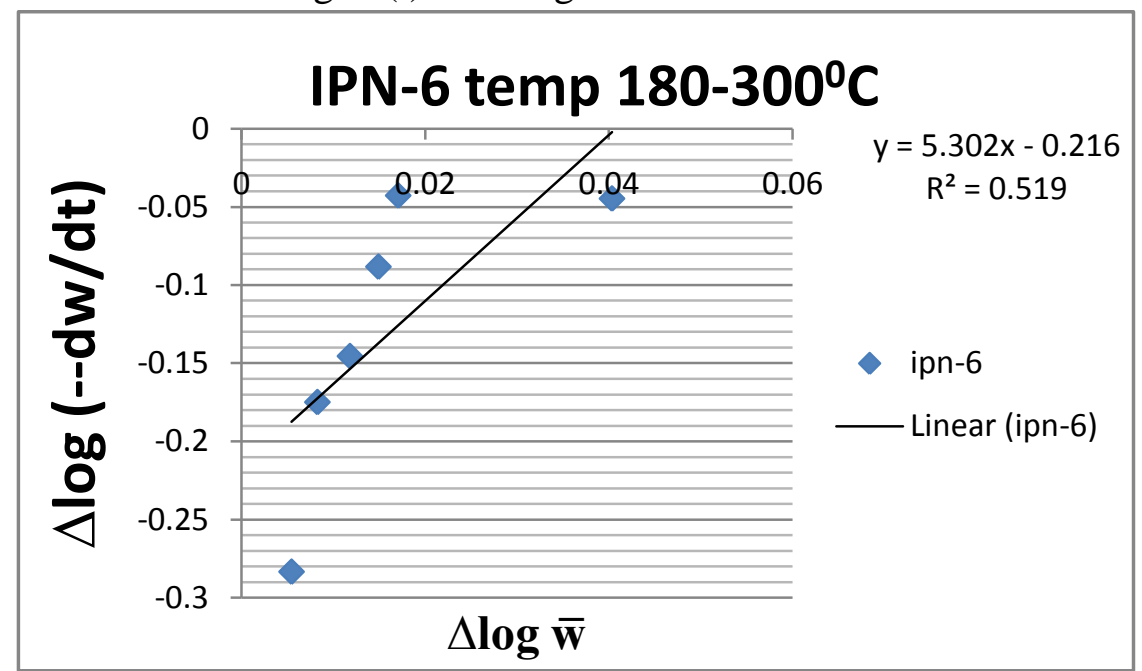

Fig 3a(ii) showing kinetics of IPN-6

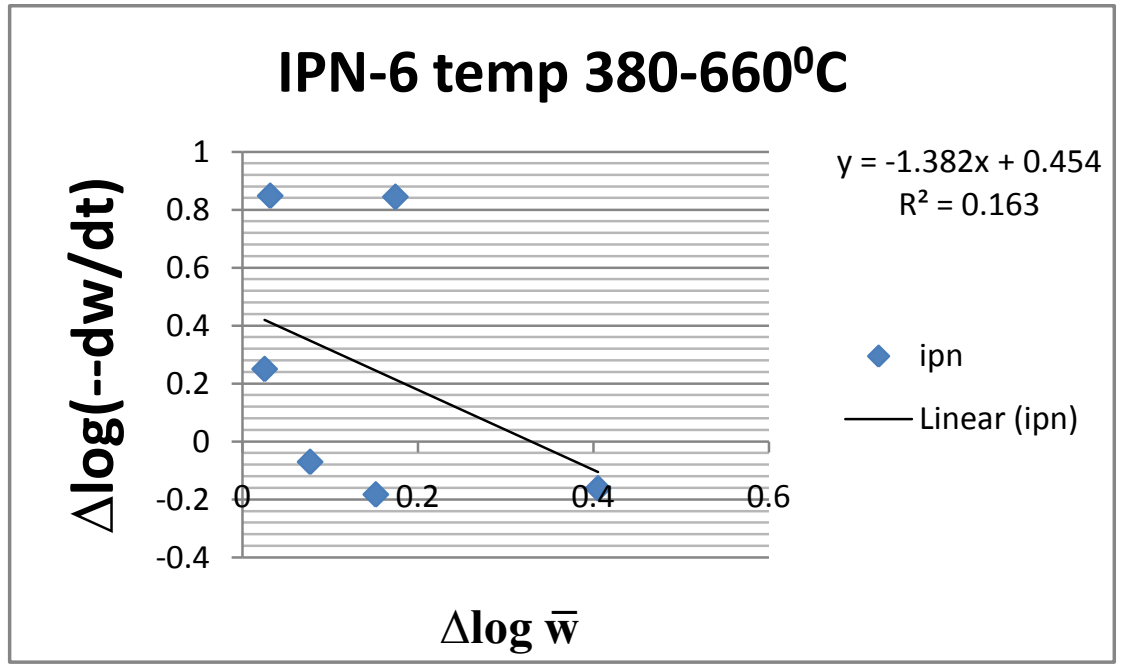

Fig 3b(i) showing kinetics of IPN-10

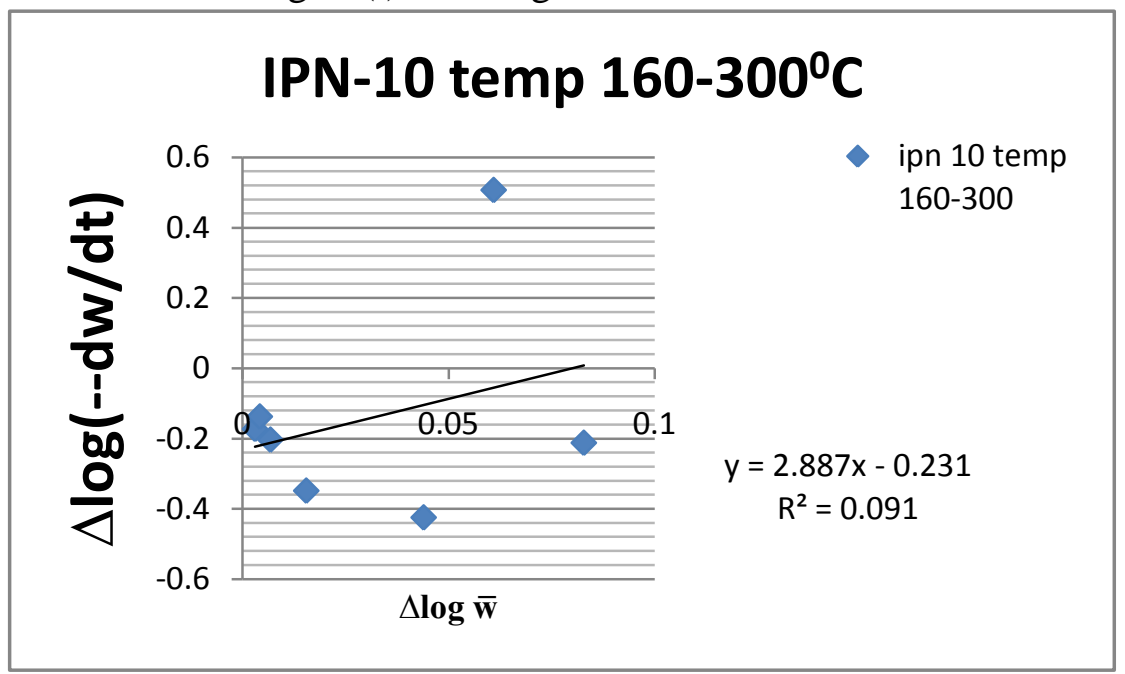


Fig 3b(ii) showing kinetics of IPN-10

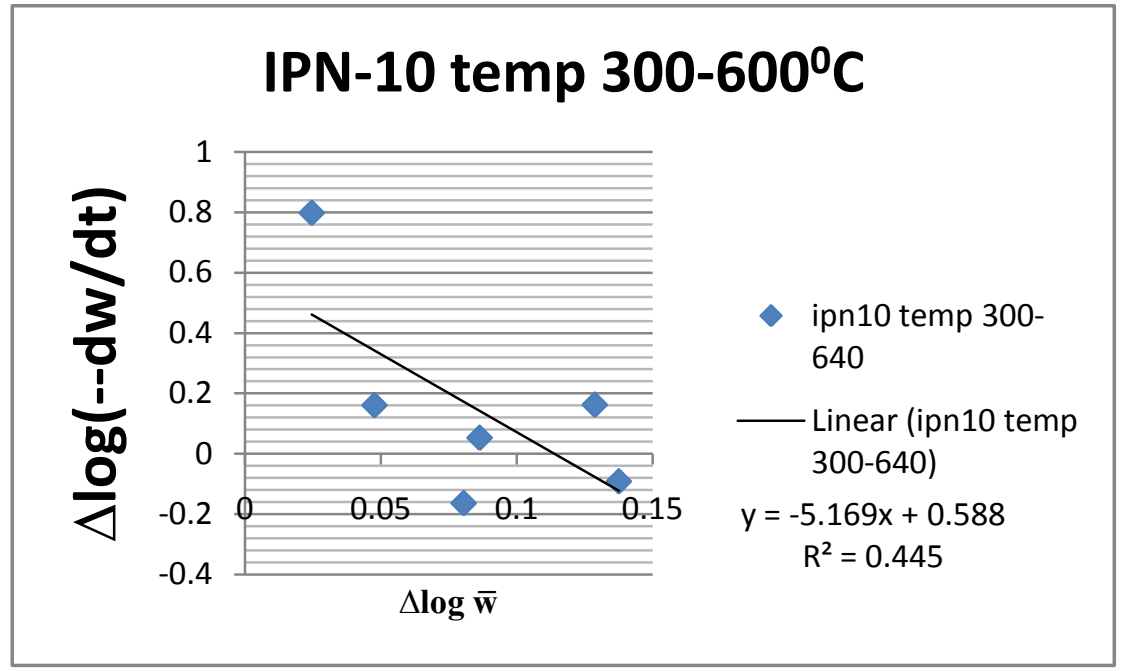

Fig 3c(i) showing kinetics of IPN-12

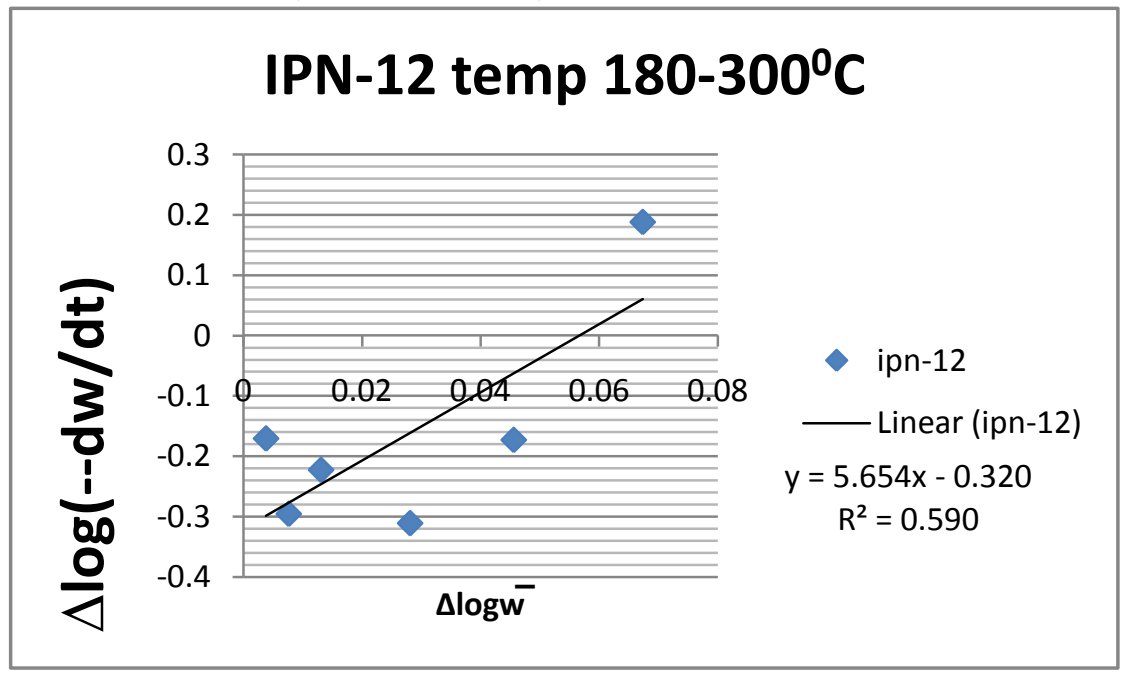

Fig 3c(ii) showing kinetics of IPN-12

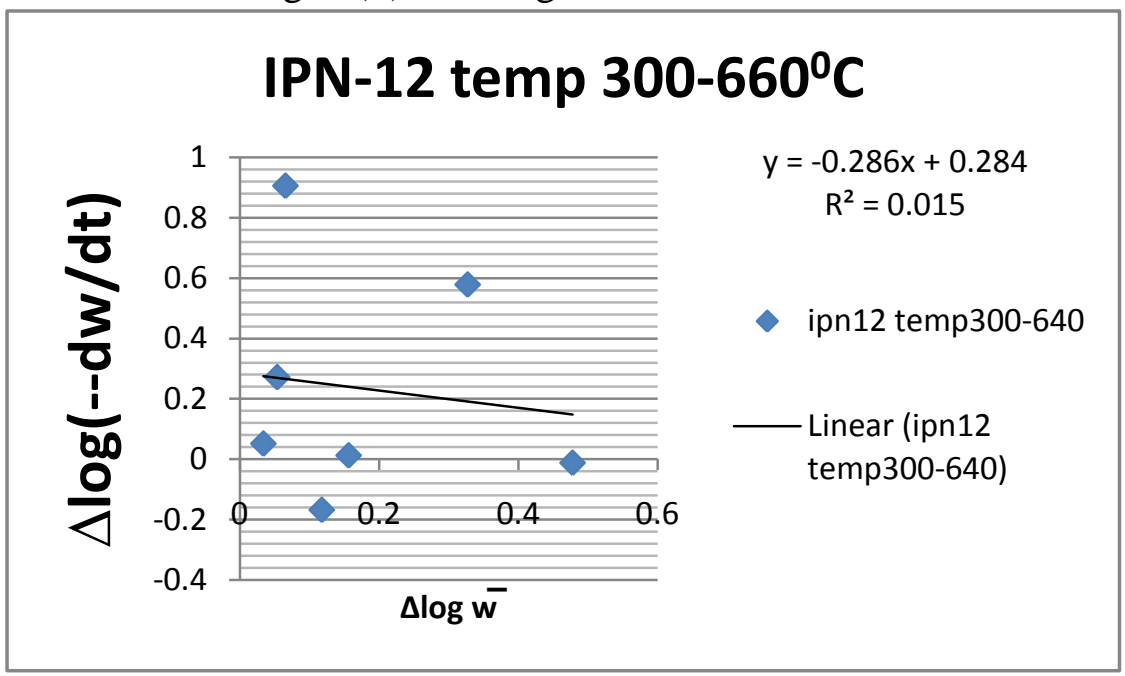


Fig 3d(i) showing kinetics of IPN-14

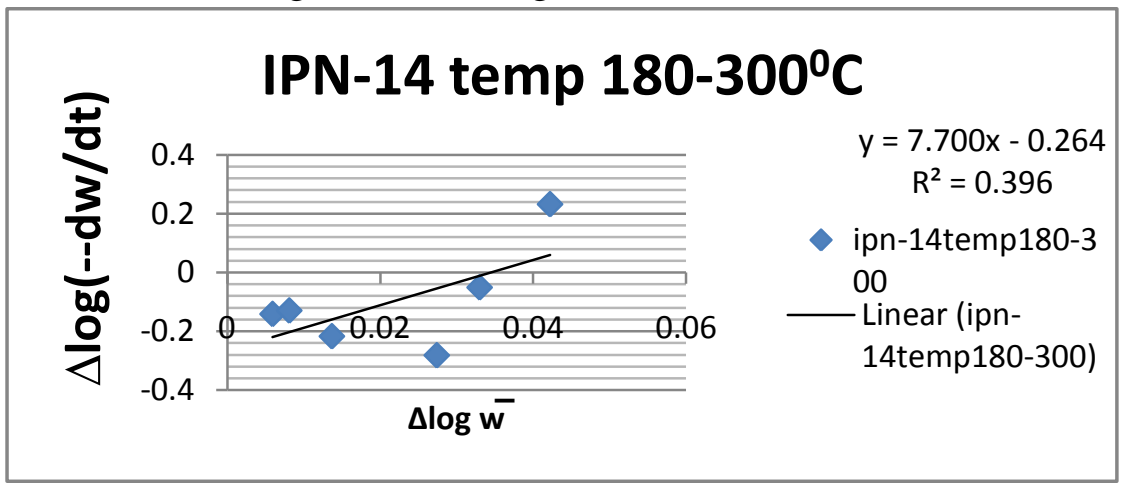

Fig 3d(ii) showing kinetics of IPN-14

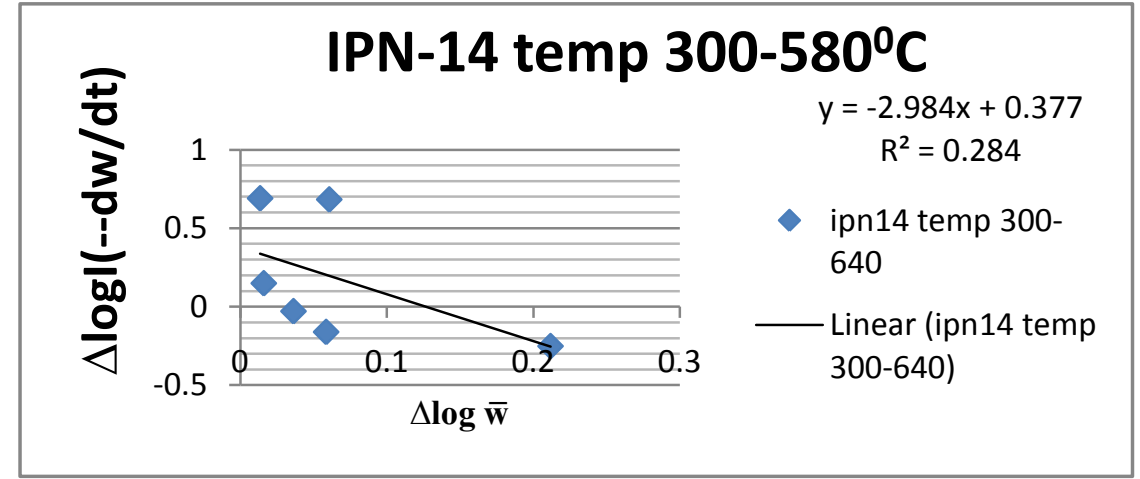

Fig 3e(i) showing kinetics of IPN-24

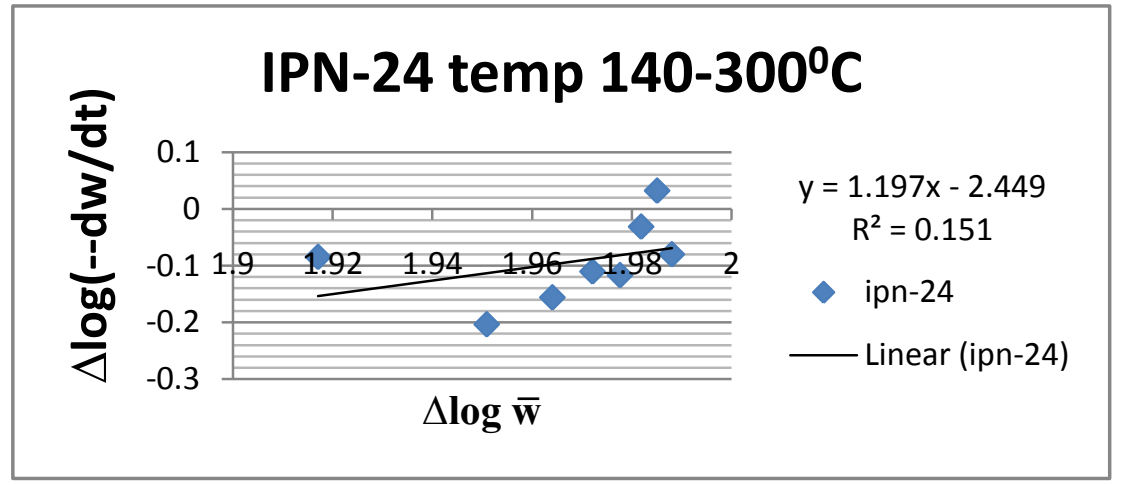

Fig 3e(ii) showing kinetics of IPN-24

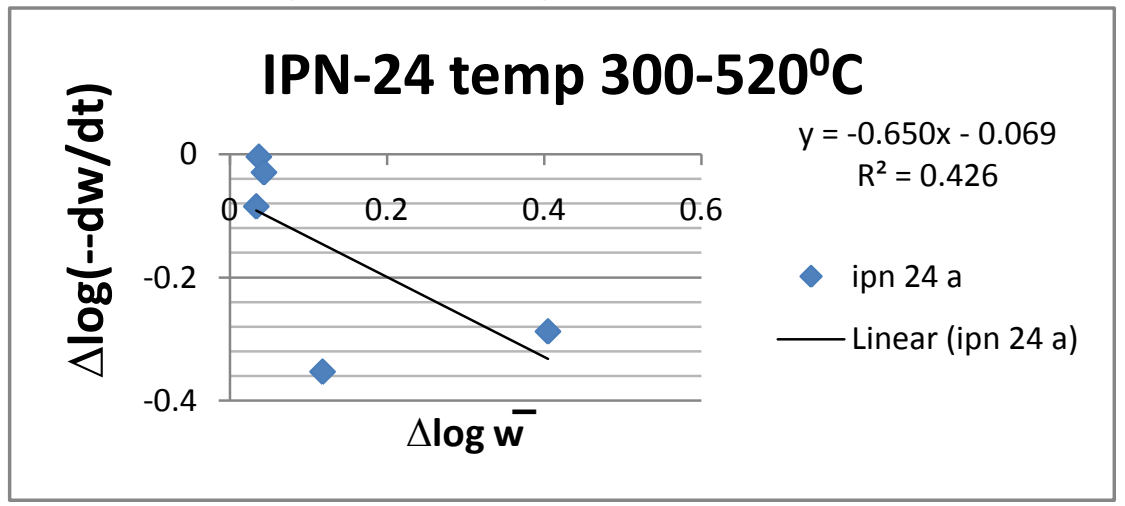


Table 1. Percentage of residual mass left with temperature

\begin{tabular}{|c|l|c|c|c|c|c|c|c|}
\hline S1 No. & $\begin{array}{l}\text { Sample } \\
\text { code }\end{array}$ & $100^{\circ} \mathrm{C}$ & $200^{\circ} \mathrm{C}$ & $300^{\circ} \mathrm{C}$ & $400^{\circ} \mathrm{C}$ & $500^{\circ} \mathrm{C}$ & $600^{\circ} \mathrm{C}$ & $700^{\circ} \mathrm{C}$ \\
\hline 1 & IPN 6 & 98.89 & 94.89 & 77.85 & 50.01 & 11.13 & 9.73 & 9.12 \\
\hline 2 & IPN10 & 97.66 & 93.92 & 58.84 & 4.9 & 20.99 & 18.37 & 17.36 \\
\hline 3 & IPN12 & 97.04 & 92.29 & 64.73 & 31.91 & 5.48 & 4.16 & 3.27 \\
\hline 4 & IPN14 & 98.18 & 92.88 & 70.94 & 54.78 & 30.05 & 28.34 & 27.76 \\
\hline 5 & IPN 24 & 98.58 & 94.48 & 82.6 & 63.09 & 11.44 & 9.61 & 9.12 \\
\hline
\end{tabular}

Table 2. Feed composition data

\begin{tabular}{|c|c|c|c|c|}
\hline S1. No. & Sample code & Composition & NCO/OH & PU/CBD \\
\hline 1 & IPN 6 & $\begin{array}{c}\text { PS+TDI+CD of 3- } \\
\text { amino benzoic acid }\end{array}$ & 1.6 & $0.50 / 0.50$ \\
\hline 2 & IPN 10 & $\begin{array}{c}\text { PS+TDI+CD of 3- } \\
\text { amino benzoic acid }\end{array}$ & 1.2 & $0.25 / 0.75$ \\
\hline 3 & IPN 12 & $\begin{array}{c}\text { PS+TDI+CD of 4- } \\
\text { amino benzoic acid }\end{array}$ & 1.2 & $0.50 / 0.50$ \\
\hline 4 & IPN 14 & $\begin{array}{c}\text { PS+TDI of 4-amino } \\
\text { benzoic acid }\end{array}$ & 1.6 & $0.35 / 0.65$ \\
\hline 5 & IPN 24 & $\begin{array}{c}\text { PS+TDI of 4-amino } \\
\text { benzoic acid }\end{array}$ & 1.6 & $0.50 / 0.50$ \\
\hline
\end{tabular}

Table 3. DSC parameter of IPNs

\begin{tabular}{|c|c|c|c|c|c|c|c|}
\hline Sl. No. & $\begin{array}{l}\text { Sample } \\
\text { Code }\end{array}$ & Composition & $\mathrm{NCO} / \mathrm{OH}$ & $\mathrm{PU} / \mathrm{CD}$ & $\mathrm{Tg}$ & Tc & $\mathrm{Tm}$ \\
\hline 1 & IPN 6 & $\begin{array}{l}\text { PS+TDI+CD of 3- } \\
\text { amino benzoic acid }\end{array}$ & 1.6 & $50: 50$ & 170.65 & 325.97 & 462.06 \\
\hline 2 & IPN10 & $\begin{array}{l}\text { PS+TDI+CD of 3- } \\
\text { amino benzoic acid }\end{array}$ & 1.2 & 25.75 & 200.11 & 231.1 & 490.31 \\
\hline 3 & IPN12 & $\begin{array}{l}\text { PS+TDI+CD of } 4- \\
\text { amino benzoic acid }\end{array}$ & 1.6 & $50: 50$ & 172.91 & 285.47 & 496.11 \\
\hline \multirow[t]{2}{*}{4} & \multirow[t]{2}{*}{ IPN14 } & \multirow{2}{*}{$\begin{array}{l}\text { PS+TDI of } 4 \text {-amino } \\
\text { benzoic acid }\end{array}$} & \multirow[t]{2}{*}{1.6} & \multirow[t]{2}{*}{$35: 65$} & \multirow[t]{2}{*}{172.1} & 231.85 & \multirow[t]{2}{*}{446.25} \\
\hline & & & & & & 414.89 & \\
\hline \multirow[t]{2}{*}{5} & \multirow[t]{2}{*}{ IPN24 } & \multirow{2}{*}{$\begin{array}{l}\text { PS+TDI+CD of 3- } \\
\text { amino benzoic acid }\end{array}$} & \multirow[t]{2}{*}{1.6} & \multirow[t]{2}{*}{$50: 50$} & \multirow[t]{2}{*}{195.02} & 310.05 & \multirow[t]{2}{*}{472.25} \\
\hline & & & & & & 437.03 & \\
\hline
\end{tabular}

Where, $\mathrm{T}_{\mathrm{g}}$ : Glass transition temperature

$\mathrm{T}_{\mathrm{c}}$ : Curie temperature or crystallization temperature

$\mathrm{T}_{\mathrm{m}}$ : The temperature at which change of state occurs

Table 4 Decomposition of IPNs by bacteria:

\begin{tabular}{|c|c|c|c|c|c|c|}
\hline S1 No. & $\begin{array}{c}\text { Sample } \\
\text { code }\end{array}$ & $\begin{array}{c}\text { Initial mass } \\
\text { in mg }\end{array}$ & $\begin{array}{c}\text { Mass after 15 } \\
\text { days in mg }\end{array}$ & $\begin{array}{c}\text { Mass after 30 } \\
\text { days in mg }\end{array}$ & $\begin{array}{c}\text { Mass after 45 } \\
\text { days in mg }\end{array}$ & $\begin{array}{c}\text { Mass after 60 } \\
\text { days in mg }\end{array}$ \\
\hline 1 & IPN 6 & 10.52 & 10.46 & 10.23 & 10.1 & 10.06 \\
\hline 2 & IPN 10 & 10.31 & 10.26 & 10.21 & 10.1 & 10.09 \\
\hline 3 & IPN 12 & 9.52 & 9.47 & 9.41 & 9.32 & 9.29 \\
\hline 4 & IPN 14 & 9.98 & 9.89 & 9.57 & 9.43 & 9.4 \\
\hline 5 & IPN 24 & 9.76 & 9.64 & 9.56 & 9.41 & 9.32 \\
\hline
\end{tabular}


Table 5. Kinetic parameters of different IPNs

\begin{tabular}{|c|c|c|c|c|}
\hline $\begin{array}{c}\text { Sample } \\
\text { Codes }\end{array}$ & $\begin{array}{c}\text { Temperature Range in } \\
{ }^{0} \mathrm{C}\end{array}$ & $\begin{array}{c}\text { Slope or Order of } \\
\text { reaction (n) }\end{array}$ & Intercept & $\begin{array}{c}\text { Activation Energy (Ea) } \\
\text { Jule/Mole }\end{array}$ \\
\hline \multirow{2}{*}{ IPN6 } & $380-660$ & 1.3821 & -0.454 & 867.81 \\
\cline { 2 - 5 } & $18-300$ & 5.3028 & -0.2163 & 413.45 \\
\hline \multirow{2}{*}{ IPN10 } & $160-300$ & 2.8877 & -0.2314 & 442.31 \\
\cline { 2 - 5 } & $300-600$ & 5.1696 & 0.5886 & 1125.10 \\
\hline \multirow{2}{*}{ IPN 12 } & $180-300$ & 5.654 & -0.3203 & 612.25 \\
\cline { 2 - 5 } & $300-600$ & 0.2861 & -0.2845 & 543.81 \\
\hline \multirow{2}{*}{ IPN14 } & $180-300$ & 7.7004 & -0.2649 & 506.35 \\
\cline { 2 - 5 } & $300-580$ & 2.9846 & -0.3778 & 722.16 \\
\hline \multirow{2}{*}{ IPN 24 } & $140-300$ & 1.1974 & -2.4496 & 4682.38 \\
\cline { 2 - 5 } & $300-520$ & 0.6507 & -0.0692 & 132.27 \\
\hline
\end{tabular}

\section{REFERENCE}

1. Sperling L.H (1977) j of polymer science macromolecules ravenshaw 12, 14.

2. Sperling L.H(1981)IPN related material plenum press New York.

3. Sperling L.H (1985) I N Walsh DJ, Higgins JS, Macronnachie A (eds), polymer blend and mixture.

4. Murthy BGK, Sivasambhan MA, Agrawal JS, Verma JK, Bhara SK, Burma M, Biddpa TS, Angew Makromo Chem 154,67,1987

5. Manjula S, Pillai CKS, Polymer News 12, 1987

6. Tyman JHP, Chem Soc Rev 8,499, 1978

7. Guru BN, Das TK, Lenka S, polymer plastic tech Eng 38(1999)

8. Troevk Grancharv G, Tsevi R, Tsekova A, J of polymer degradation and stability (2000) 41,7017- 7022

9. Praharaj D, Pal NC, Patra S, Lenka S, 2004, Int Jof plastic tech 8(172-179)

10. Sharma V, Kundu PP, Progress in polymer science, 33,12(,1199-1215) 2008

11. Yadav R, Srivastava D, European polymer journal (2009)

12. Gopalkrishnan S, Sujatha, Research J of Phar Biol and Chemical Sc (2011) RJBCS Vol 2 issue 3 (1069)

13. Biswal S, Satapathy JR, Achary PGR , Pal NC , Springer sc + Business Media LLC(2012)

14. Gopalkrishnan S, Nevaditha,Mythili CV, Scholars of research laboratory(2012) 